\title{
Industry and research should meet to develop new opportunites for U.S. oceanography
}

James Yoder

$\mathbf{T}$

his April in Miami, Oceanology International Americas 2001, TOS and others are trying something not yet common in U.S. oceanography. We are participants in a meeting that brings ocean industry and research together under a common roof and in a common forum. Many oceanography meetings include large exhibit sections with many exhibitors, but the Miami meeting goes a step beyond that. As an oceanographic researcher what are the possible advantages of building closer links with ocean industry?

One of the most obvious advantages involves instrument development. Like other scientists, oceanographers use many general-purpose laboratory and field instruments, but we also need specialized instrumentation to make measurements in a pretty tough environment. Many oceanographic applications, however, represent a very small potential market, which is of interest only to very small companies. Such companies have limited capabilities and funds for research and development and cannot afford to invest in many product lines. They need to know very specifically what oceanographers need and want to measure and with what accuracy and precision. Face-to-face conversations are one of the best ways to exchange information that can lead to new products and new applications.

For university-based oceanographers and oceanography students, closer links with industry may open up private sector employment opportunities for new oceanography graduates. Check the employment statistics for oceanography graduates on the Consortium for Ocean Research and Education (CORE) web page, particularly for Ph.D. graduates (http://core.cast.msstate.edu/emp2.html). The overwhelming majority of new oceanography Ph.D.s take jobs and postdoctoral fellowships with universities, research institutions or with federal labs. Very few (about $10 \%$ ) are employed in private industry, and this percentage has been constant over the past decade. Is this by choice and for lack of opportunity, or is it because most oceanography graduate students get very little exposure to ocean industry? Closer links between industry and researchers involved in training graduate students, as well as between industry and graduate students during the first year or two of their doctoral training, could change this pattern and open up some new employment possibilities for our graduates. In addition, internships and training grants can help pay for graduate student education. More funding often brings more students, and more students bring more resources to our academic departments.

If you work for a university like mine, there is another important reason for wanting to learn more about ocean industry. A few years ago, my oceanography school was criticized in the business section of our major state newspaper, because we received a relatively large investment from our state but showed very little economic impact as measured by spin-off industry. The author of the article suggested that state money might be better invested in other areas such as computers, biotechnology, etc. which in other states and regions creates considerable economic activity. Well, of course we answered with many reasons why oceanography should not be evaluated in such a manner (and some of these reasons are even valid). Nevertheless, we also took the criticism to heart and tried to get our university more involved with creating ocean industry. But it is not easy. Most oceanography professors do not know much about the business world, with its short timetables and harsh funding realities. University administrators (at least at our university) struggle with some aspects of university/industry partnerships, including procedures for co-locating private sector personnel in university space, how to award solesource contracts and subcontracts to companies that are partners in agency-funded proposals, how to give credit for entrepreneurship in tenure and promotion evaluations and other issues. Most of these issues have been solved in engineering, business and some other fields, but my impression is that oceanography is still a traditional academic field at most U.S. universities where these issues are not resolved. Should we try to change, and if so, what are the advantages and opportunities?

Our meeting in Miami is good place to come to begin your own investigation into such questions and to evaluate for yourself the opportunities that might arise from better communication between ocean industry and ocean research.

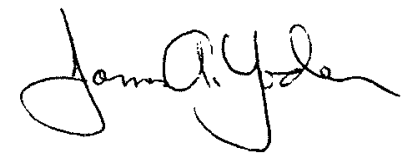

